\title{
Cytotoxic Evaluation and DNA Binding Ability of Catalytically Synthesized New Steroidal Lactones
}

\author{
Ashraf Mashrai ${ }^{1 *}$, Ayaz Mahmood Dar ${ }^{13}$, Shafia Mir ${ }^{3}$, Himanshu Gupta ${ }^{2}$ and Shamsuzzaman ${ }^{1}$ \\ ${ }^{1}$ Department of Chemistry, Aligarh Muslim University, Aligarh- 202002, India \\ ${ }^{2}$ Department of Chemistry, Indian Institute of Technology, Roorkee- 247667, India \\ ${ }^{3}$ Department of Chemistry, Govt Degree College Kulgam (University of Kashmir) India
}

\begin{abstract}
In an attempt to find a new class of cytotoxic agents, a series of fused steroidal derivatives containing lactone moiety were prepared via Michael addition reaction of $\alpha, \beta$-unsaturated steroidal ketones with ethyl chloroacetate in basic medium. The characterization of novel compounds was accomplished by spectroscopic techniques such as IR, ${ }^{1} \mathrm{H}$ NMR, ${ }^{13} \mathrm{C}$ NMR, Mass spectrometry and elemental analysis. The compounds were screened for in vitro cytotoxicity against some particular human cancer cell lines using the MTT assay during which the compound 4 and 5 depicted potential anticancer behavior after showing $I_{50}=19.41 \mu \mathrm{mol} \mathrm{L}^{-1}$ and $19.27 \mu \mathrm{mol} \mathrm{L}^{-1}$ against HeLa and MCF-7 cell line, respectively. The Gel electrophoresis demonstrated that steroidal lactone showed strong interaction during the concentration dependent cleavage activity with pBR322 DNA. The molecular docking study suggested the non-covalent bonding of steroidal lactones in minor groove of DNA. The results revealed that the synthesized compounds have better prospectus to act as cancer chemotherapeutic candidates which warrants further in vivo anticancer investigations.
\end{abstract}

Keywords: Steroidal lactone; Ethyl chloroacetate; Anticancer; MTT assay

\section{Introduction}

Cancer is a disease in which the control of growth is lost in one or more cells, leading either to a solid mass of cells known as a tumour or to a liquid cancer (i.e. blood or bone marrow-related cancer). It is one of the leading causes of death throughout the world, in which the main treatments involve surgery, chemotherapy, and/or radiotherapy. Chemotherapy involves the use of drugs to selectively destroy tumour cells or at least limit their proliferation. The use of chemotherapy began in the 1940s with nitrogen mustards, which are extremely powerful alkylating agents, and antimetabolites. Since the early success of these initial treatments, a large number of additional anticancer drugs have been developed $[1,2]$ which, to date are not totally successful interferences. Therefore, anticancer drug design is a very active area in medicinal chemistry and over the past few decades extensive research has led to the development of many chemotherapeutic agents. However, none of these agents are able to eliminate the cancer completely $[3,4]$. The limitations of current anticancer drugs and rapid development of drug resistance [5-7] have highlighted the need for the discovery of new anticancer agents, preferably with novel mechanisms of action.

The modified steroidal derivatives have been a rich source of candidates with potential pharmaceutical applications that have encouraged the design and synthesis of new analogs with increased pharmacological activity. Recently, several steroidal derivatives have been investigated as new curative agents for cancers [8-10]. In addition, a great number of the modified steroids containing $\alpha, \beta$ -unsaturated ketone described as anticancer agents [11-13]. Moreover, a, $\beta$-unsaturated carbonyl steroids fused heterocyclic rings were indicated as an aromatase inhibitors to resist cancers [14]. Inspired by the prior art, we became interested in developing heterosteroid compounds, in which pharmacologically crucial structural elements from two molecules are combined to produce a non-identical twin drug, is a rational approach to obtain therapeutically useful molecules. In view of the facts mentioned above, and in continuation with our earlier work [15], we herein report the synthesis of new steroidal derivatives clubbed with lactone moiety with the aim of investigating their cytotoxic behavior.

\section{Experimental}

\section{Chemistry}

All chemicals were purchased from Sigma-Aldrich and Merck (India) and were used without further purification. Melting points were recorded Kofler apparatus and were uncorrected. IR spectra were recorded on $\mathrm{KBr}$ pellets with Pye Unicam SP3-100 spectrophotometer and values are given in $\mathrm{cm}^{-1} .{ }^{1} \mathrm{H}$ and ${ }^{13} \mathrm{C}$ spectra in dilute $\mathrm{CDCl}_{3}$ solutions at $303 \mathrm{~K}$ were run on a Bruker Avance DRX $500 \mathrm{NMR}$ spectrometer equipped with a $5 \mathrm{~mm}$ diameter broad band inverse probehead working at $500 \mathrm{MHz}$ for ${ }^{1} \mathrm{H}$ and at $125 \mathrm{MHz}$ for ${ }^{13} \mathrm{C}$, respectively. ${ }^{1} \mathrm{H}$ chemical shifts were referenced to the trace signal of $\mathrm{CHCl}_{3}$ (7.26 ppm from int. TMS) and ${ }^{13} \mathrm{C}$ chemical shifts to the center peak of the solvent signal (77.00 ppm from int. TMS). The following abbreviations were used to indicate the peak multiplicity s-singlet, $\mathrm{d}-$ doublet, $\mathrm{t}$-triplet, $\mathrm{m}$-multiple and values are given in parts per million $(\mathrm{ppm})(\delta)$. Mass spectra were recorded on a JEOL SX 102/ DA-6000 Mass Spectrometer. Analytical data of C, H, N were within $0.04 \%$ of the theoretical values and were obtained using Carlo Erba Analyzer. Thin layer chromatography (TLC) plates were coated with silica gel G and exposed to iodine vapours to check the homogeneity as well as the progress of reaction. Sodium sulphate (anhydrous) was used as a drying agent.

\section{General procedure for the syntheses of the steroidal lactone derivatives (4-6)}

To a solution of steroidal $\alpha, \beta$-unsaturated ketone $\mathbf{1 - 3}(1 \mathrm{mmol})$

*Corresponding author: Ashraf Mashraia, Department of Chemistry, Aligarh Muslim University, Aligarh- 202002, India, Tel: +96 7739899435: E-mail:ashraf.yemen@yahoo.com; ayazchem09@gmail.com

Received January 23, 2017; Accepted January 28, 2017; Published January 31, 2017

Citation: Mashrai A, Dar AM, Mir S, Gupta H, Shamsuzzaman (2017) Cytotoxic Evaluation and DNA Binding Ability of Catalytically Synthesized New Steroidal Lactones. Nat Prod Chem Res 5: 251. doi: 10.4172/2329-6836.1000251

Copyright: @ 2017 Mashrai A, et al. This is an open-access article distributed under the terms of the Creative Commons Attribution License, which permits unrestricted use, distribution, and reproduction in any medium, provided the original author and source are credited. 
in ethanol $(10 \mathrm{~mL})$, ethyl chloroacetate $(1 \mathrm{mmol})$ and few drops of piperidine were added. The reaction mixture was refluxed for 12-15 h. After completion of reaction, as determined by TLC, the reaction mixture was diluted with water and extracted thoroughly with ether. The extracts were washed successively with water and dried over anhydrous sodium sulfate $\left(\mathrm{Na}_{2} \mathrm{SO}_{4}\right)$. Evaporation of solvents gave the crude product which was recrystallized from methanol to obtain pure products as steroidal lactones 4-6.

3'-Chloro-3', 4'-dihydro-3 $\beta$-acetoxy-5a-cholestano[5,7-c d]-2HLactone (4): Yellow powder, Yields (80\%); M.p. $123^{\circ} \mathrm{C}$;Anal.Calc. for $\mathrm{C}_{31} \mathrm{H}_{47} \mathrm{ClO}_{4}$ : C,71.26, $\mathrm{H}, 8.98$. found: $\mathrm{C}, 71.28, \mathrm{H}, 8.99$; IR (KBr) $\mathrm{cm}^{-1}$ : $1735(\mathrm{OCOCCl}), 1712\left(\mathrm{OCOCH}_{3}\right), 1615(\mathrm{C}=\mathrm{C}), 1142(\mathrm{C}-\mathrm{O}), 754(\mathrm{C}-$ $\mathrm{Cl}) ;{ }^{1} \mathrm{H}$ NMR $\left(\mathrm{CDCl}_{3}, 500 \mathrm{MHz}\right): \delta 5.3\left(\mathrm{~s}, 1 \mathrm{H}, \mathrm{C}_{6} \mathrm{H}\right), 4.4\left(\mathrm{~s}, 1 \mathrm{H}, \mathrm{C}_{3}^{\prime} \mathrm{H}\right)$, $4.6\left(\mathrm{~m}, 1 \mathrm{H}, \mathrm{C}_{3} \mathrm{\alpha}-H, W^{1} / 2=12 \mathrm{~Hz}, \mathrm{~A} / \mathrm{B}\right.$ trans $), 2.21\left(\mathrm{~s}, 3 \mathrm{H}, \mathrm{OCOCH}_{3}\right), 1.12$ $\left(\mathrm{s}, 3 \mathrm{H}, \mathrm{C}_{10} H\right), 1.06\left(\mathrm{~s}, 3 \mathrm{H}, \mathrm{C}_{19} H\right), 0.87\left(\mathrm{~d}, 6 \mathrm{H}, \mathrm{C}_{26} \mathrm{H}, \mathrm{C}_{27} H\right), 0.78(\mathrm{~s}, 3 \mathrm{H}$, $\left.\mathrm{C}_{18} H\right), 0.71\left(\mathrm{~s}, 3 \mathrm{H}, \mathrm{C}_{13} H\right), 0.92\left(\mathrm{~d}, 3 \mathrm{H}, \mathrm{C}_{21} H\right), 0.92$ and 0.85 (other side chain methyl groups). ${ }^{13} \mathrm{C} \mathrm{NMR}\left(\mathrm{CDCl}_{3}, 125 \mathrm{MHz}\right): \delta 170,162,150$, $122,70,66,57,48,43,42,40,39,36,35,34,33,32,31,29,28,27,26,25$,

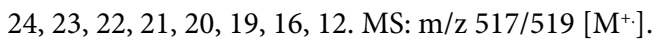

3'-Chloro-3',

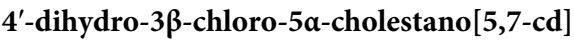
-2H-Lactone (5): Yellow powder, Yields (78\%); M.p. $122^{\circ} \mathrm{C}$; Anal.Calc. for $\mathrm{C}_{29} \mathrm{H}_{44} \mathrm{Cl}_{2} \mathrm{O}_{2}$ : C, 70.14, H, 8.90. found: C, 70.29, H, 8.95 ; IR ( $\left.\mathrm{KBr}\right)$ $v \mathrm{~cm}^{-1}: 1732(\mathrm{OCOCCl}), 1612(\mathrm{C}=\mathrm{C}), 1140(\mathrm{C}-\mathrm{O}), 749,752(2 \times \mathrm{C}-\mathrm{Cl})$ ; ${ }^{1} \mathrm{H}$ NMR $\left(\mathrm{CDCl}_{3}, 500 \mathrm{MHz}\right): \delta 5.1\left(\mathrm{~s}, 1 \mathrm{H}, \mathrm{C}_{6} \mathrm{H}\right), 4.2\left(\mathrm{~s}, 1 \mathrm{H}, \mathrm{C}_{3}{ }^{\prime} \mathrm{H}\right), 3.8$ $\left(\mathrm{m}, 1 \mathrm{H}, \mathrm{C}_{3} \mathrm{\alpha}-H, W^{1 / 2}=12 \mathrm{~Hz}, \mathrm{~A} / \mathrm{B}\right.$ trans $), 1.12\left(\mathrm{~s}, 3 \mathrm{H}, \mathrm{C}_{10} H\right), 1.06(\mathrm{~s}, 3 \mathrm{H}$, $\left.\mathrm{C}_{19} H\right), 0.87\left(\mathrm{~d}, 6 \mathrm{H}, \mathrm{C}_{26} \mathrm{H}, \mathrm{C}_{27} H\right), 0.78\left(\mathrm{~s}, 3 \mathrm{H}, \mathrm{C}_{18} H\right), 0.71\left(\mathrm{~s}, 3 \mathrm{H}, \mathrm{C}_{13} H\right)$, $0.92\left(\mathrm{~d}, 3 \mathrm{H}, \mathrm{C}_{21} \mathrm{H}\right), 0.92$ and 0.85 (other side chain methyl groups). ${ }^{13} \mathrm{C}$ NMR ( $\left.\mathrm{CDCl}_{3}, 125 \mathrm{MHz}\right): \delta 162,150,122,66,59,53,49,44,43,42,41$, $40,37,36,34,33,32,31,29,28,27,26,25,24,23,22,19,16,12 . \mathrm{MS}: \mathrm{m} / \mathrm{z}$ $491 / 493\left[\mathrm{M}^{+}\right]$.

3'-Chloro-3', 4'-dihydro-5a-cholestano [5,7-cd]-2H-Lactone (6): Yellow powder, Yields (76\%); M.p. $124^{\circ} \mathrm{C}$; Anal. Calc. for $\mathrm{C}_{29} \mathrm{H}_{45} \mathrm{ClO}_{2}$ : C, 75.34, H, 8.91. found: C, 75.54, H, 9.84 ; IR (KBr) $v \mathrm{~cm}^{-1}: 1730$ (OCOCCl), $1614(\mathrm{C}=\mathrm{C}), 1145(\mathrm{C}-\mathrm{O}) 751(\mathrm{C}-\mathrm{Cl}) ;{ }^{1} \mathrm{H}$ NMR $\left(\mathrm{CDCl}_{3}, 500\right.$ $\mathrm{MHz}): \delta 5\left(\mathrm{~s}, 1 \mathrm{H}, \mathrm{C}_{6} H\right), 4.3\left(\mathrm{~s}, 1 \mathrm{H}, \mathrm{C}_{3}{ }^{\prime} H\right), 1.12\left(\mathrm{~s}, 3 \mathrm{H}, \mathrm{C}_{10} H\right), 1.06(\mathrm{~s}, 3 \mathrm{H}$, $\left.\mathrm{C}_{19} H\right), 0.87\left(\mathrm{~d}, 6 \mathrm{H}, \mathrm{C}_{26} \mathrm{H}, \mathrm{C}_{27} H\right), 0.78\left(\mathrm{~s}, 3 \mathrm{H}, \mathrm{C}_{18} H\right), 0.71\left(3 \mathrm{H}, \mathrm{s}, \mathrm{C}_{13} H\right)$, $0.92\left(\mathrm{~d}, 3 \mathrm{H}, \mathrm{C}_{21} \mathrm{H}\right), 0.92$ and 0.85 (other side chain methyl groups). ${ }^{13} \mathrm{C}$ NMR ( $\left.\mathrm{CDCl}_{3}, 125 \mathrm{MHz}\right): \delta 162,150,122,66,56,48,45,44,43,40,38$, $37,36,35,34,31,29,28,27,26,25,24,23,22,21,20,19,16,12$. MS: $\mathrm{m} / \mathrm{z} 459 / 457\left[\mathrm{M}^{+\cdot}\right]$.

\section{In vitro cytotoxicity}

Cell lines and culture conditions: Human cancer cell lines HeLa (human cervical cancer cells) / ATCC (CCL-2), A549 (human lung carcinoma cells) / ATCC (CCL- 185), MCF-7 (breast cancer cells) / ATCC (HTB-22) and HL-60 (human Leukaemia) / ATCC (CCL240) were taken for the study. A549 and HL-60 cells were grown in RPMI 1640 supplemented with $10 \%$ foetal bovine serum (FBS), 10 $\mathrm{U}$ penicillin and $100 \mu \mathrm{g} / \mathrm{mL}$ streptomycin at $37^{\circ} \mathrm{C}$ with $5 \% \mathrm{CO}_{2}$ in a humidified atmosphere. HeLa cells and MCF-7 were grown in Dulbecco's modified Eagle's medium (DMEM) supplanted with FCS and antibiotics as described above for RPMI 1640. Fresh medium was given every second day and on the day before the experiments were done. Cells were passaged at preconfluent densities, using a solution containing $0.05 \%$ trypsin and $0.5 \mathrm{mM}$ EDTA.

Cell viability assay (MTT): The anticancer activity in vitro was measured using the MTT assay. The assay was carried out according to known protocol $[16,17]$. Exponentially growing cells were harvested and plated in 96-well plates at a concentration of $1 \times 10^{4}$ cells/well. After $24 \mathrm{~h}$ incubation at $37^{\circ} \mathrm{C}$ under a humidified $5 \% \mathrm{CO}_{2}$ to allow cell attachment, the cells in the wells were respectively treated with target compounds at various concentrations for $48 \mathrm{~h}$. The concentration of DMSO was always kept below $1.25 \%$, which was found to be nontoxic to the cells. A solution of 3-(4,5-dimethylthizao1-2-y1)-2,5diphenyltetrazolium bromide (MTT), was prepared at $5 \mathrm{mg} / \mathrm{mL}$ in phosphate buffered saline (PBS; $1.5 \mathrm{mM} \mathrm{KH}_{2} \mathrm{PO}_{4}, 6.5 \mathrm{mM} \mathrm{Na} 2 \mathrm{HPO}_{4}$, $137 \mathrm{mM} \mathrm{NaCl}, 2.7 \mathrm{mM} \mathrm{KCl}$; pH 7.4). $20 \mu \mathrm{l}$ of this solution were added to each well. After incubation for $4 \mathrm{~h}$ at $37^{\circ} \mathrm{C}$ in a humidified incubator with $5 \% \mathrm{CO}_{2}$, the medium/MTT mixtures were removed, and the formazan crystals formed by the mitochondrial dehydrogenase activity of vital cells were dissolved in $100 \mu \mathrm{l}$ of DMSO per well. The absorbance of the wells was read with a microplate reader (Bio-Rad Instruments) at $570 \mathrm{~nm}$. Effects of the drug cell viability were calculated using cell treated with DMSO as control.

Data analysis: Cell survival was calculated using the formula: Survival $(\%)=[$ (absorbance of treated cells-absorbance of culture medium)/(absorbance of untreated cells - absorbance of culture medium) $] \times 100[18,19]$. The experiment was done in triplicate and the inhibitory concentration (IC) values were calculated from a dose response curve. $\mathrm{IC}_{50}$ is the concentration in ' $\mu \mathrm{M}$ ' required for $50 \%$ inhibition of cell growth as compared to that of untreated control. $\mathrm{IC}_{50}$ values were determined from the linear portion of the curve by calculating the concentration of agent that reduced absorbance in treated cells, compared to control cells, by $50 \%$. Evaluation is based on mean values from three independent experiments, each comprising at least six microcultures per concentration level.

\section{Gel Electrophoresis}

Two concentrations (50 and $100 \mu \mathrm{M})$ of compounds and $3 \mu \mathrm{l}$ of $0.5 \mu \mathrm{g} / \mu \mathrm{l}$ of pUC19 DNA was loaded with $2 \mu \mathrm{l}$ of EtBr into $1 \%$ agarose gel. The final volume of the reaction mixture for all the wells of gel was $10 \mu \mathrm{l}$. The DNA band was visualized under UV transilluminator [20].

\section{Molecular Docking}

The rigid molecular docking studies were performed using HEX 6.1 software [21]. The steroidal lactone was taken for the following docking study. The crystal structure of the B-DNA dodecamer d(CGCAAATTTCGC)2 (PDB ID: 1BNA) was downloaded from the protein data bank. All calculations were carried out on an Intel CORE $\mathrm{i}$, 3.1 GHz based machine running MS Windows XP as the operating system. First, the water molecules were deleted. The DNA was enclosed in a box with number of grid points in $\mathrm{x} \times \mathrm{y} \times \mathrm{z}$ directions, $76 \times 78 \times$ 120 and a grid spacing of $0.375 \AA$. All calculations were carried out on an Intel CORE i5, 3.1 GHz based machine running MS Windows XP as the operating system. Visualization of the docked pose have been done using Discovery Studio 3.5 molecular graphics program.

\section{Results and Discussion}

\section{Chemistry}

Easily accessible steroidal $\alpha, \beta$-unsaturated ketones 1-3 were synthesized by literature method [22]. The substrates used for initial studies are $3 \beta$-acetoxycholest-5-en-7-one 1, 3 $\beta$-chlorocholest-5-en7-one 2 and cholest-5-en-7-one 3 when allowed to react with ethyl chloroacetate in the present of few drops of piperidin in absolute ethanol 
to afforded $3^{\prime}$-chloro- $3^{\prime}, 4^{\prime}$-dihydro-3 $\beta$-acetoxy- $5 \alpha$ cholestano[5,7-c d]$2 H$-Lactone 4, 3'-chloro- $3^{\prime}, 4^{\prime}$-dihydro $-3 \beta$-chloro- $5 \alpha$ cholestano[5,7-c d]-2H-Lactone 5 and $3^{\prime}$-chloro-3', $4^{\prime}$-dihydro-5a cholestano- [5,7-c d]$2 \mathrm{H}$-Lactone $\mathbf{6}$ as shown in (Scheme $\mathbf{1}$ ).
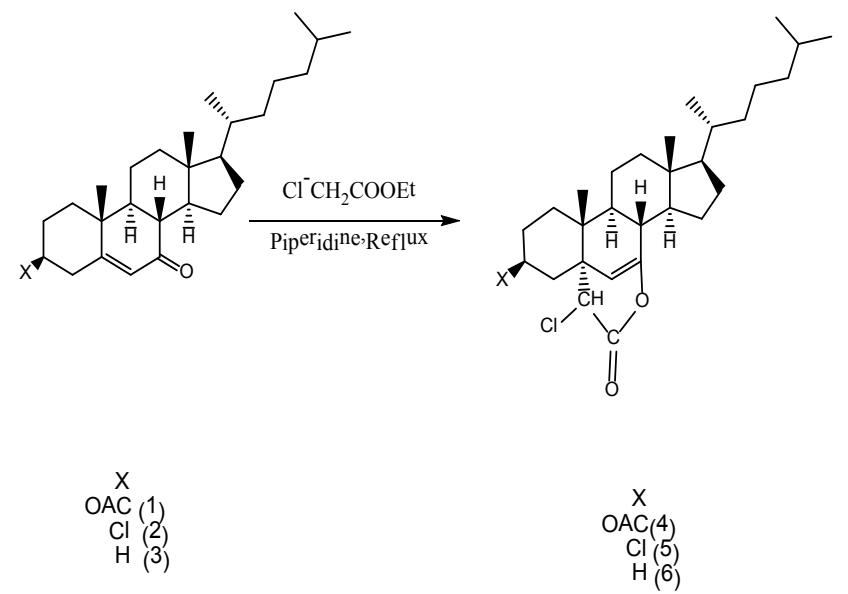

Scheme 1: Showing the formation of steroidal lactones (4-6).

The yield of products was in the range of $76-80 \%$. The products have been characterized based on their spectral (IR, ${ }^{1} \mathrm{H}$ NMR, ${ }^{13} \mathrm{C}$ NMR and MS) studies and elemental analysis. The selected diagnostic bands of IR spectra of synthesized products provide useful information for determining structures of the lactone derivatives. All the compounds 4-6 exhibited absorption bands at $1735-1730 \mathrm{~cm}^{-1}$ due to $(\mathrm{OCOCCl})$ and $1612-1615 \mathrm{~cm}^{-1}$ due to $\mathrm{C}=\mathrm{C}$. The absorption band at $1140-1141$ $\mathrm{cm}^{-1}$ as ascribed to the $\mathrm{C}-\mathrm{O}$ which also confirmed the formation of lactone rings in all compounds and the absorption band at 749-754 $\mathrm{cm}^{-1}$ assigned to $\mathrm{C}-\mathrm{Cl}$ which also conformed by Beilstein test [23]. The structure of the lactone derivatives was further confirmed by ${ }^{1} \mathrm{H}$ NMR spectra, which proves as a diagnostic tool for the positional elucidation of the proton. Assignments of signals are based on chemical shift and intensity pattern. The ${ }^{1} \mathrm{H}$ NMR shows showed one singlet in the region $\delta 5-5.3$ for $\left(\mathrm{C}_{6} \mathrm{H}\right)$, signal as a singlet at $\delta 4.2-4.4$ indicating the presence $\left(\mathrm{C}_{3}{ }^{\prime}-H\right.$, lactone ring). The broad multiple signal appeared at $\delta 3.8-4.6$ $\left(\mathrm{C}_{3} \mathrm{a}-\mathrm{H}, \mathrm{W}^{1 / 2}=12 \mathrm{~Hz}\right)$ attributed to $\mathrm{C}_{3} \alpha-H(\mathrm{~A} / \mathrm{B}$ ring junction trans). Other prominent peaks of steroidal nucleus in the compounds 4-6 were observed at their characteristic positions and are given in experimental section. ${ }^{13} \mathrm{C}$ NMR spectrum of the compounds also supported the proposed structure. All the compounds exhibited signals at $\delta 162$ due to $(\mathrm{OCOCCl})$. Signals at $\delta 150-122$ for $\mathrm{C}_{7}$ and $\mathrm{C}_{6}$ and signals at $\delta 66$ due to $\mathrm{C}_{3}$ ' of the lactone ring are also observed. In MS, the distinctive signals were observed, the mass spectra of compounds 4-6 which followed the definite fragmentation pattern. The molecular ion peaks $\left(\mathrm{M}^{+}\right)$for compounds 4-6 were observed at $\mathrm{m} / \mathrm{z}$ 517/519, 491/493 and 459/457 respectively. The stereochemical assignation has been performed based on half band width $\left(W_{1 / 2}\right)$ value of $\mathrm{C}_{3}$-axial proton in the ${ }^{1} \mathrm{H}$ NMR spectra of compounds $\mathbf{4}$ and $\mathbf{5}$ which clearly suggested that $\mathrm{A} / \mathrm{B}$ ring junction is trans [24] and based on model chemistry which suggest that the attack of enolate it must be from $(\alpha)$ side which is less hindered compare to $(\beta)$ which is more hindered due to present of $C_{10}$ methyl.

Based on foregoing discussion, a tentative mechanism has been proposed for the formation of steroidal lactone via Michael addition reaction (Scheme 2) which involve in first step, removes the acidic $a$-hydrogen by piperidin giving the reactive enolate. In second step, nucleophilic enolate will attack the conjugated ketone at the electrophilic alkene in nucleophilic addition type process afforded the intermediate, which subsequently underwent intramolecular cyclization to give the ultimate compounds 4-6.

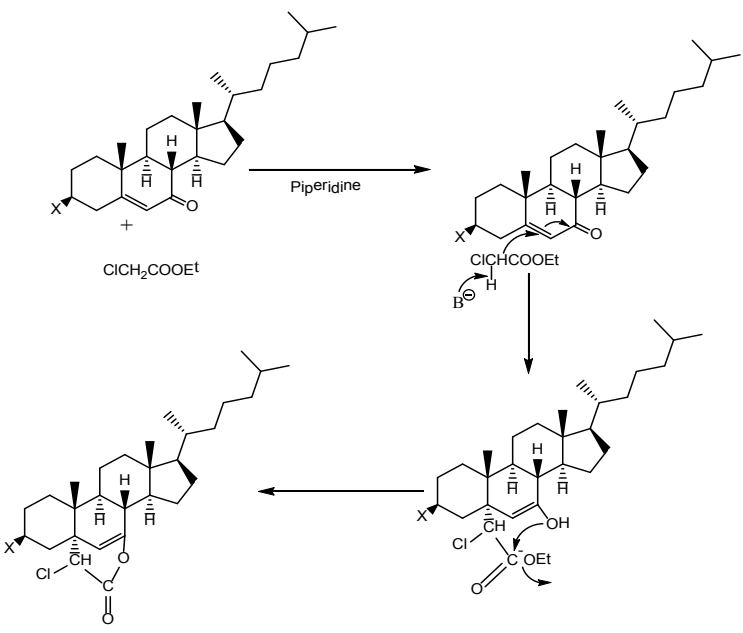

Scheme 2: Mechanism showing the formation of steroidal lactones.

\section{In vitro cytotoxicity}

In vitro evaluation of anticancer activity of the synthesized compounds was carried out using the 3-(4,5-dimethylthiazol-2-yl)2,5-diphenyltetrazolium bromide (MTT) assay [16]. The conversion of the soluble yellowish MTT to the insoluble purple formazan by active mitochondrial lactate dehydrogenase of living cells has been used to develop an assay system for measurement of cell proliferation. Cell viability was measured with the purple formazan that was metabolized from MTT mitochondrial lactate dehydrogenase, which is active only in live cells. The screening of compounds 4-6 (Table 1) was done using the human cancer cell lines lines; HeLa (human cervical cancer cells) / ATCC (CCL-2), A549 (human lung carcinoma cells) / ATCC (CCL- 185), MCF-7 (breast cancer cells) / ATCC (HTB-22) and HL60 (human Leukaemia) / ATCC (CCL-240). Anticancer potency of the compounds was indicated by $\mathrm{IC}_{50}$ values that were calculated by linear regression analysis of the concentration-response curves obtained for each compound. Anticancer study showed that the compound 5 was most active towards MCF-7 cell among the four cancer cell lines with $\mathrm{IC}_{50}=19.41 \pm 0.7$ while the compound $\mathbf{5}$ was more active against HeLa with $\mathrm{IC}_{50}=19.27 \pm 0.8$. These results support the previous studies that steroids can regulate a variety of biological processes and specific potential drug candidates for the treatment of leukaemia and breast cancers [25]. The results indicate that the presence of electron withdrawing groups chlorine and acetoxy at position $3 \beta$ has an impact on the bioactivity of the compounds [26,27]. It is worth pointing out that $3^{\prime}$-chloro-3',4-dihydro-5a cholestano [5,7-c d]-2H-lactone derivatives 4-6 are not only potent but also selective against cancer cell lines, specifically against breast and leukemia cells, compared to the other cancer cell lines.

\begin{tabular}{|c|c|c|c|c|}
\hline \multicolumn{5}{|c|}{$\mathbf{I C}_{\mathbf{5 0}}\left(\mathbf{\mu m o l ~ I}^{-1}\right)^{\mathbf{a}}$} \\
\hline Compound & A549 & HeLa & HL-60 & MCF-7 \\
\hline S4 & $29.32 \pm 0.2$ & $19.41 \pm 0.7$ & $23.21 \pm 0.9$ & $34.71 \pm 0.3$ \\
\hline $\mathbf{5}$ & $45.44 \pm 1.3$ & $>50$ & $31.71 \pm 0.2$ & $19.27 \pm 0.8$ \\
\hline $\mathbf{6}$ & $>50$ & $27.17 \pm 0.5$ & $>50$ & $27.12 \pm 0.7$ \\
\hline
\end{tabular}

- Cell-growth inhibition was analyzed by the MTT assay.

- ${ }^{a} I_{50}$ is the concentration of compound that inhibits $50 \%$ of cell growth.

Table 1: Showing anticancer activity data of compound 4-6 against Human cancer cell lines. 


\section{Gel Electrophoresis Assay}

All the compounds (4-6) were examined for their binding abilities with DNA by agarose gel electrophoresis. At low concentration, the compounds (4-6) do not show any visible change in the band intensity of DNA (lane 2, 4, 6). However, at higher concentrations band intensity gets decreased by compounds 4-6 (lane 3, 5, 7). Thus electrophoretic pattern demonstrate that all the compounds interact with DNA. The loss in the band intensity at higher concentration may be assumed due to the non-covalent binding mode of the compounds 4-6 to DNA, which in turn results in the displacement of EtBr, as depicted by molecular docking studies. In case of lane 2, 4, 6 the concentration of the compounds is not sufficient for the displacement of EtBr. In the Figure 1, lane 1 contains DNA only, lane 2, 4, 6 contains DNA and $50 \mu \mathrm{M}$ of compounds 4-6 and lane 3, 5, 7 contain DNA and $100 \mu \mathrm{M}$ of compounds 4-6. This conclusion was further supported from the fluorescence studies, which also gave evidence for interaction of the compounds with DNA.

\section{Molecular Docking}

The molecular docking technique is an attractive tool to get insight of the mechanistic study, by placing a molecule into the binding site of the target specific region of the DNA. In our experiment, rigid molecular docking (two interacting molecules were treated as rigid bodies) studies were performed with HEX 6.1 software to predict the binding modes of compounds with a DNA duplex of sequence $\mathrm{d}$ (CGCAAATTTCGC) ${ }_{2}$ dodecamer (PDB ID: 1BNA), and provide an energetically favourable docked structures (DNA-steroidal lactone shown in Figure 2). It is evident from the figure that these type of compounds gets attached with DNA through minor groove and their lactone moiety shows groove binding between the nucleotide base pairs. The docked steroidal lactone-DNA complex is shown in Figure 2 which depicts that during the binding there is no hydrogen bonding between the steroidal lactone in between the base pairs of minor groove but literature reveals that intercalating forces like van der Waals forces are much more important than hydrogen bonding of the compound to the base pairs of DNA [21]. In this configuration, the group at $3 \beta$-axial position (i.e., X-moiety) remains inclined towards the phosphodiester bond of DNA and the possibility of $\mathrm{H}$ - bonding cannot be ruled out.

Since the changes in accessible surface area of interacting residues show a preferential binding of compound between G-C base pairs and bends the DNA slightly in such a way that a part of the steroidal lactone comes between the two base pairs of the minor groove of DNA helix. The resulting relative binding energy of docked steroidal lactone-DNA complex was found to be $-279.72 \mathrm{kJmol}^{-1}$. This value is consistent with the high binding constant obtained from spectroscopic techniques.

\section{Conclusion}

The present work involves the simple and convenient strategy for the synthesis of steroidal lactones in reasonably good yields. During cytotoxicity experiments (MTT assay) the compound $\mathbf{5}$ has been identified showing potential anticancer behaviour of $\mathrm{IC}_{50}=19.27$ against MCF-7 cell line. This study also supports the reported studies about specialty of steroid as anticancer against leukaemia and breast cancer [25]. The molecular docking studies undertaken in the present work are in total agreement with the non-covalent mode of binding (minor groove binding). The gel electrophoresis revealed that compounds depicted concentration dependent DNA strand scission.

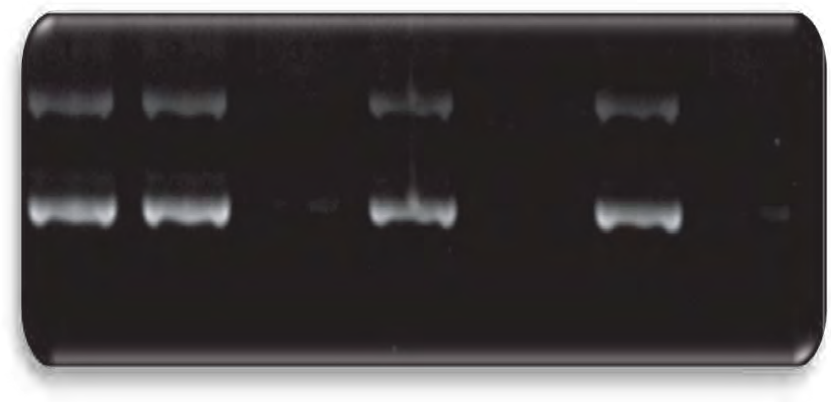

Figure 1: Agarose gel electrophoresis of reaction mixtures containing DNA and compounds 4-6 lane 1, DNA only, lanes 2, 3 DNA and 4 (50 and 100 $\mu \mathrm{M})$, lanes 4, 5 DNA and $5(50$ and $100 \mu \mathrm{M})$ and lanes 6, 7 DNA and 6 (50 and $100 \mu \mathrm{M})$.

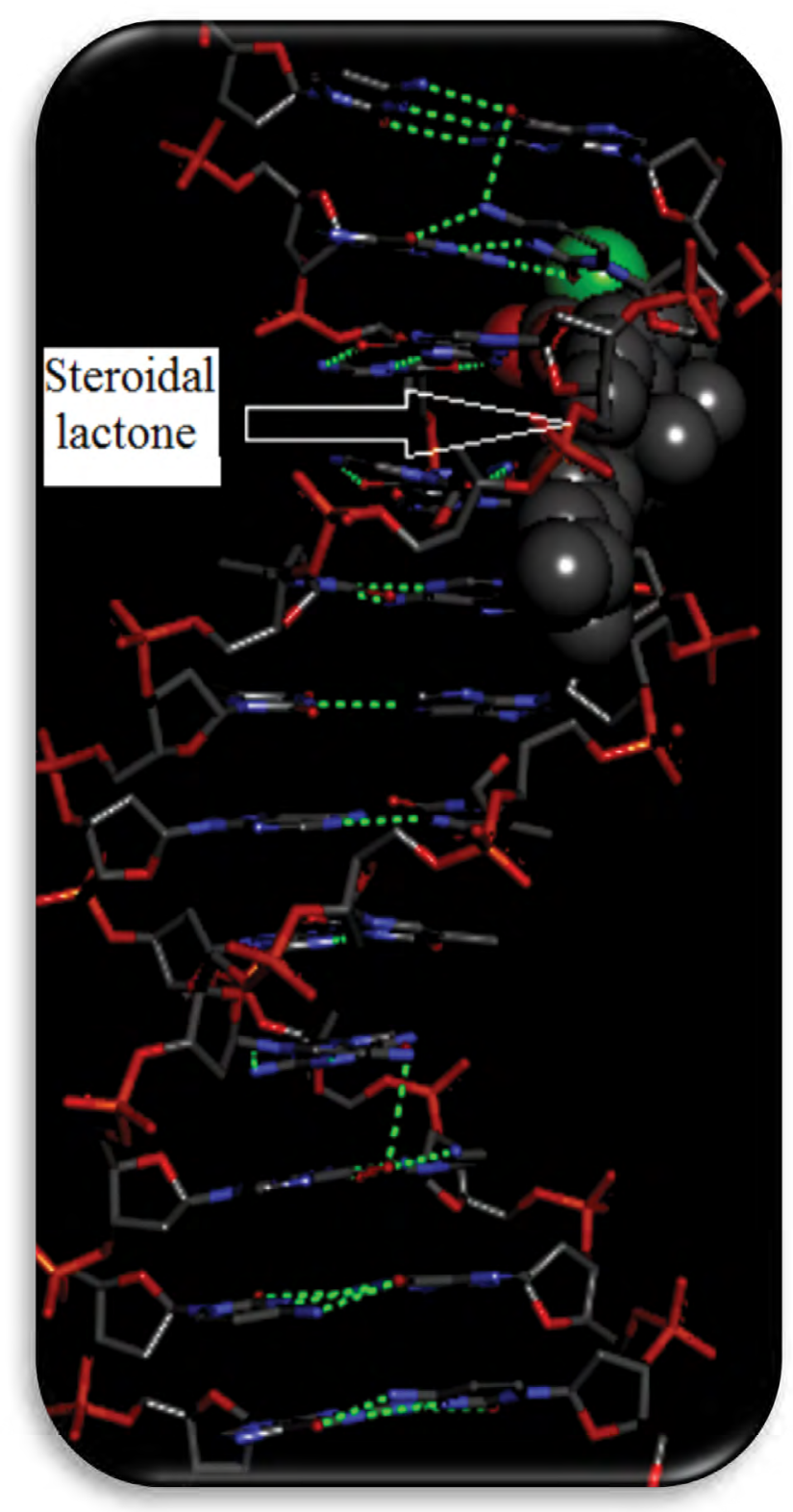

Figure 2: Molecular docked model of steroidal lactone with DNA dodecamer duplex of sequence d(CGCGAATTCGCG) $)_{2}$ (PDB ID: 1BNA). 
Citation: Mashrai A, Dar AM, Mir S, Gupta H, Shamsuzzaman (2017) Cytotoxic Evaluation and DNA Binding Ability of Catalytically Synthesized New Steroidal Lactones. Nat Prod Chem Res 5: 251. doi: 10.4172/2329-6836.1000251

In conclusion, the synthesized compounds have better prospectus to act as cancer chemotherapeutic candidates which warrants further in vivo anticancer investigations.

\section{Acknowledgement}

The authors thank the Chairman, Department of Chemistry, A.M.U., Aligarh for providing necessary research facilities. Facilities provided by SAP for their generous research support are also gratefully acknowledged. Authors (AM and AMD) also thank UGC India for research fellowship. Authors also thank Prof Shamsuzzaman for the successful completion of the work.

\section{References}

1. Shewach DS, Kuchta RD (2009) Introduction to cancer chemotherapeutics. Chem Rev 109: 2859-2861.

2. Thurston DE (2007) Chemistry and Pharmacology of Anticancer Drugs, CRC Press. Taylor and Francis Group, Boca Raton.

3. Cragg GM, Newman DJ (2005) Plants as a source of anticancer agents. J Ethnopharmacology 100: 72-79.

4. Cragg GM, Grothaus PG, Newman DJ (2009) Impact of natural products on developing new anti-cancer agents. Chem Rev 109: 3012-3043.

5. Sreedhar AS, Csermely $P(2004)$ Heat shock proteins in the regulation of apoptosis: new strategy in tumor therapy: a comphrensive review. Pharmacol Ther 101: 227-257.

6. McCubrey JA, Steelman LS, Abrams SL, Lee JT, Chang F, et al. (2006) Roles of the RAF/MEK/ERK and P13K /PTEN/ AKT pathways in malignant transformation and drug resistance. Adv Enzyme Regul 46: 249-279.

7. Pechan PM (1991) Heat shock proteins and cell proliferation. FEBS Lett 280

8. Edmondson RJ, Monaghan JM (2001) The epidemiology of overian cancer. Int J Gynecol Cancer 11: 423-429.

9. Maria J, Ghini AA, Gerardo B (2003) 6, 19-carbon-bridged steroids. Synthesis of 6, 19-methanoprogesterone. Org Biomol Chem 1: 939-943.

10. Tian Dong L, Jing Xia Z, Jun X, ShuJia Z, Yi Jun H, et al. (2010) Synthesis and anti-glioma activity of $25(R)$-spirostan-3 $\beta, 5 \alpha, 6 \beta, 19$-tetrol. Steroids 75 : 224-229.

11. Jiang C, Huang C, Feng B, Li J, Gong J, et al. (2010) Synthesis and antitumor evaluation of methyl spongoate analogs. Steroids 75: 1153-1163.

12. Carney JR, Yoshida WY, Scheuer PJ (1992) Kiheisterones, new cytotoxic steroids from a Maui sponge. J Org Chem 57: 6637-6643.
13. Yan XH, Lin LP, Ding J, Guo YW (2007) Methyl spongoate, a cytotoxic steroid from the sanya soft coral spongodes sp. Bioorg. Med Chem Lett 17: 2661-2663.

14. Yadav MR, Sabale PM, Rajani G, Zimmer C, Haupenthal J, et al. (2011) Synthesis of some novel androstanes as potential aromatase inhibators. Steroids 76: 464-470.

15. Shamsuzzaman HK, Dar AM, Siddiqui N, Rehman S (2016) Synthesis, characterization, antimicrobial and anticancer studies of new steroidal pyrazolines. J Saudi Chem Soc 20: 7-12.

16. Slater TF, Sawyer B, Strauli U (1963) Studies on succinate tetrazolium reductase systems. III. Points of coupling of four different tetrazolium salts III. Points of coupling of four different tetrazolium salts. Biochim Biophys Acta 77 383-393.

17. Mosmann T (1983) Rapid colorimetric assay for cellular growth and survival: Application to proliferation and cytotoxicity assays. J Immunol Methods 65: 55-63.

18. Saxena HO, Faridi U, Kumar JK, Luqman S, Darokar MP, et al. (2007) Synthesis of chalcone derivatives on steroidal framework and their anticancer activities. Steroids 72: 892-900.

19. Woerdenbag HJ, Moskal TA, Pras N, Malingre TM, El-Feraly FS, et al. (1993) Cytotoxicity of artemisinin-related endoperoxides to Ehrlich ascites tumor cells. J Nat Prod 56: 849-856.

20. Shamsuzzaman, Dar AM, Sohail A, Bhat S, Mustafa MF, et al. (2014) Synthesis molecular docking and biological evaluation of new steroidal $4 \mathrm{H}$-pyrans. Spectrochimica Acta Part A: Mol Biomol Spectroscopy 117: 493-501.

21. Mustard D, Ritchie DW (2005) Docking essential dynamics eigen structures. Proteins: Struct Bioinf 60: 269-274.

22. Dauben WG, Takemura KH (1953) A study of the mechanism of conversion of acetate to cholesterol via squalene. J Am Chem Soc 75: 6302-6304.

23. Beilstein $F$ (1872) On the detection of chlorine bromine and iodine in organic subastances. European Journal of Inorganic Chemistry 5: 620-621.

24. Bhacca NS, Williams DH (1964) Application of NMR spectroscopy in organic chemistry, illustrations from the steriod field.

25. Minorics R, Szekeres T, Krupitza G, Saiko P, Giessrigl B, et al. (2011) Antiproliferative effects of some novel synthetic solanidine analogs on HL-60 human leukemia cells in vitro. Steroids 76: 156-162.

26. Carvalho JFS, Silva MMC, Moreira JN, Simoes S, Melo MLS (2010) Sterols as anticancer agents: synthesis of ring-B oxygenated steroids, cytotoxic profile and comphrensive SAR analysis. J Med Chem 53: 7632-7638.

27. Seong BC, Yon K, Young Yun MI, Byung ZA (2004) 5-Arylidene-2(5H)-Furanone derivatives: synthesis and structure-activity relationship for cytotoxicity. Arch Pharm Res 5: 485-494. 